Article

\title{
The Distinctive Effects of Glucose-Derived Carbon on the Performance of Ni-Based Catalysts in Methane Dry Reforming
}

\author{
UPM Ashik ${ }^{1}{ }^{\circledR}$, Shusaku Asano ${ }^{1}{ }^{\circledR}$, Shinji Kudo ${ }^{1}$, Doan Pham Minh $\left.{ }^{2} \mathbb{(}\right)$, Srinivas Appari ${ }^{3}$, \\ Einaga Hisahiro ${ }^{4}$ and Jun-ichiro Hayashi ${ }^{1,5, *}$ \\ 1 Institute for Materials Chemistry and Engineering, Kyushu University, 6-1, Kasuga Koen, \\ Kasuga 816-8580, Japan; urampully@cm.kyushu-u.ac.jp (U.A.); shusaku_asano@cm.kyushu-u.ac.jp (S.A.); \\ shinji_kudo@cm.kyushu-u.ac.jp (S.K.) \\ 2 RAPSODEE CNRS UMR-5302, IMT Mines Albi, Université de Toulouse, CT CEDEX 09, 81013 Albi, France; \\ Doan.phamminh@mines-albi.fr \\ 3 Department of Chemical Engineering, Birla Institute of Technology and Science, Pilani, \\ Rajasthan 333 031, India; srinivas.appari@pilani.bits-pilani.ac.in \\ 4 Faculty of Engineering Sciences, Kyushu University, 6-1, Kasuga Koen, Kasuga, Fukuoka 816-8580, Japan; \\ einaga.hisahiro.399@m.kyushu-u.ac.jp \\ 5 Transdisciplinary Research and Education Center of Green Technology, Kyushu University, \\ Kasuga 816-8580, Japan \\ * Correspondence: junichiro_hayashi@cm.kyushu-u.ac.jp; Tel.: +81-92-583-7796
}

Received: 29 November 2019; Accepted: 20 December 2019; Published: 23 December 2019

\begin{abstract}
This study aimed to investigate the effect of carbon derived from glucose (C) on the physicochemical characteristics and catalytic activity of $\mathrm{Ni}$, supported over $\mathrm{SiO}_{2}, \mathrm{ZSM}-5$, and $\mathrm{TiO}_{2}$ in methane dry reforming. Among the $\mathrm{Ni}$ catalysts without $\mathrm{C}, \mathrm{Ni} / \mathrm{SiO}_{2}$ exhibited the highest $\mathrm{CH}_{4}-\mathrm{CO}_{2}$ conversion and stability at all experimented temperatures. On the other hand, the C-incorporated catalysts prepared by glucose impregnation, followed by pyrolysis, showed dissimilar performances. $\mathrm{C}$ improved the stability of $\mathrm{Ni} / \mathrm{SiO}_{2}$ in the reforming at $650{ }^{\circ} \mathrm{C}$ and $750{ }^{\circ} \mathrm{C}$ and increased the $\mathrm{CH}_{4}$ and $\mathrm{CO}_{2}$ conversion to the level close to the thermodynamic equilibrium at $850{ }^{\circ} \mathrm{C}$. However, this element did not substantially affect the activity of Ni/ZSM- 5 and exerted a retarding effect on $\mathrm{Ni} / \mathrm{TiO}_{2}$. Characterizations with $\mathrm{H}_{2}$-TPD, XRD, EXAFS, and STEM-EDS revealed that the different influences of $C$ by the supports were attributed to the extent of metal dispersion and metal-support interaction.
\end{abstract}

Keywords: methane dry reforming; syngas; Ni-catalyst; $\mathrm{ZSM}-5 ; \mathrm{SiO}_{2} ; \mathrm{TiO}_{2} ;$ glucose-derived carbon; metal dispersion

\section{Introduction}

Since the start of modern recordkeeping in 1880, the warmest earth surface was documented in 2016, and 17 of the 18 warmest years ever recorded occurred from 2001 [1]. The major cause of this massive global warming is the anthropogenic greenhouse gas (GHG) emissions, chiefly consisting of $\mathrm{CO}_{2}$ and $\mathrm{CH}_{4}$ [2]. Studies conclusively validate the huge upsurge of average global tropospheric $\mathrm{CO}_{2}$ concentration from $315 \mathrm{ppm}$ to $408 \mathrm{ppm}$ in the 60 years since 1958 [3]. A similar increasing trend has been observed for $\mathrm{CH}_{4}$ as well. The average global tropospheric $\mathrm{CH}_{4}$ concentration was $1850 \mathrm{ppb}$ in 2017, which was only $1630 \mathrm{ppb}$ in 1984 [4]. A firm and favorable change in the current trend of global warming could be achieved by coupling GHG emission reductions and transforming $\mathrm{CO}_{2}$ and $\mathrm{CH}_{4}$ to value-added products [5-7]. Here is the advantage of dry reforming of methane (DRM), which converts $\mathrm{CH}_{4}-\mathrm{CO}_{2}$ gas mixture to $\mathrm{H}_{2}$ and $\mathrm{CO}$ with a ratio that fits for Fischer-Tropsch (F-T) synthesis. 
Combining DRM with syngas conversion for liquid hydrocarbons, fuels, and other industrial products will substantially decrease GHG emission and our preposterous reliance on fossil fuel. As per the theoretical findings of Akiyama et al. [8], the thermal energy of high-temperature waste heat, e.g., from a solid oxide fuel cell or steel industry [9], can be converted to chemical energy in DRM process, thus making the overall process of $\mathrm{CO}_{2}-\mathrm{CH}_{4}$ elimination exceptionally environmentally-friendly.

Various transition and noble metal catalysts have been utilized to reduce reaction temperature and increase the syngas yield. However, the major challenges include the high cost of noble metals, the requirement of nanosized catalysts and catalysts deactivation by carbon deposition, and thermal sintering. Irrespective of their advantages of low or no carbon deposition and high activity, noble metals $(\mathrm{Rh}, \mathrm{Ru}, \mathrm{Pt})$ are not extensively used in industry due to their high cost [10]. Among the investigated catalysts, Ni-based catalysts have received remarkable interest because of their cost-effective availability and good activity and selectivity in syngas [11]. Furthermore, highly dispersed Ni-based catalysts exhibit reasonable intrinsic activity. However, active phase sintering and/or huge carbon formation and subsequent catalyst deactivation are the major concerns that inhibit the scale-up and commercial practice of these materials [11]. In addition, side reactions, such as water gas shift, methanation, Boudouard reaction, $\mathrm{CO}$ decomposition, and methane decomposition, collectively and individually cause low product yield.

Extensive investigations are reported on improving catalytic activity and reducing deactivation, and the predominantly investigated topics include metal loading [12], pretreatment [13], catalyst preparation methods [14], second-metal doping [15], and support modification [16]. Researchers unitedly explained the importance of proper support that improves the active phase dispersion. As a result, the total textural properties could lead to outstanding product selectivity and catalyst stability. Many researchers investigated and successfully modified catalysts with $\mathrm{CeO}_{2}$ or the oxides of other base metals $(\mathrm{Na}, \mathrm{K}, \mathrm{Mg}$, and $\mathrm{Ca}$ ) to suppress carbon deposition $[17,18]$. However, the utilization of inexpensively available carbon precursors for Ni-based catalyst improvement is poorly investigated. Li et al. [19] observed poor catalytic performance in the presence of doped carbon. They improved the catalytic performance by pretreating with $\mathrm{CO}_{2}$; however, pretreatment with $\mathrm{H}_{2}$ and $\mathrm{N}_{2}$ were not competitive. The deposited carbon after $\mathrm{CO}_{2}$ pretreatment enforced the metal-support interaction and suppressed carbon deposition over the active catalyst surface during DRM. To the best of authors' knowledge, no comparative study has been conducted on the catalytic performance of carbon-doped $\mathrm{Ni}$-catalysts supported on various materials.

In this study, we comprehensively examined the distinctive effect of in situ produced carbon from glucose during the preparation of Ni-catalyst supported over $\mathrm{SiO}_{2}, \mathrm{ZSM}-5$, and $\mathrm{TiO}_{2}$ on the physicochemical characteristics and catalytic activity toward DRM. The impregnation method was used to synthesize Ni-supported and C-doped catalysts with a constant metal loading (10 wt.\%). DRM activity of the catalysts was investigated in a fixed-bed reactor at temperatures in the range of $650-850{ }^{\circ} \mathrm{C}$ by using a feed gas mixture of $\mathrm{CH}_{4} / \mathrm{CO}_{2}$ (molar ratio $=1 / 1$ ).

\section{Results and Discussions}

\subsection{Dry Reforming of Methane}

DRM experiments were conducted using $\mathrm{CH}_{4}$ and $\mathrm{CO}_{2}$ feed gas mixture with a molar ratio of $1 / 1$ at three different temperatures $\left(650^{\circ} \mathrm{C}, 750^{\circ} \mathrm{C}\right.$, and $\left.850^{\circ} \mathrm{C}\right)$. The composition of the gaseous product was recorded every $4 \mathrm{~min}$. The catalyst with deposited carbon was collected after each experiment and then characterized. Conversions of $\mathrm{CH}_{4}$ and $\mathrm{CO}_{2}$ with investigated catalysts at different temperatures are shown in Figures 1 and 2, respectively. Corresponding $\mathrm{H}_{2}$ and $\mathrm{CO}$ yields are exhibited in Figures $\mathrm{S} 1$ and $\mathrm{S} 2$, respectively.

Among the investigated catalysts, $\mathrm{SiO}_{2}$-supported catalysts presented exceptional activity and stability regardless of the C-promotion effect. All investigated catalysts showed an increasing trend of feed gas conversion with increasing temperature. For example, the initial $\mathrm{CH}_{4}$ conversion for $\mathrm{Ni}-\mathrm{C} / \mathrm{SiO}_{2}$ 
catalyst was increased from $44 \%$ at $650{ }^{\circ} \mathrm{C}$ to $91 \%$ at $850{ }^{\circ} \mathrm{C}$. The deactivation rate of non-doped and $\mathrm{C}$-doped $\mathrm{Ni} / \mathrm{SiO}_{2}$ catalysts was high at low temperatures. Ni-based catalysts are substantially active from $600{ }^{\circ} \mathrm{C}$ to $750{ }^{\circ} \mathrm{C}$ to decompose methane and produce C-deposits $\left(\mathrm{CH}_{4} \rightarrow 2 \mathrm{H}_{2}+\mathrm{C}\right.$, $\Delta \mathrm{H}=74.5 \mathrm{~kJ} / \mathrm{mol})$ [20]. Throughout this process, side reaction $\left(\mathrm{C}+\mathrm{CO}_{2} \rightarrow 2 \mathrm{CO}\right)$ might not be well executed at low reaction temperatures and resulted in the production of graphitic carbon species, which block the active sites from the reaction medium. The high graphitic carbon deposition at $650{ }^{\circ} \mathrm{C}$ over Ni-based catalysts was confirmed via XRD analysis, as shown later. This phenomenon subsequently led to gradual deactivation. By contrast, the advanced stability of $\mathrm{Ni}-\mathrm{C} / \mathrm{SiO}_{2}$ was observed at $850{ }^{\circ} \mathrm{C}$, with $91 \%$ initial methane conversion and $87 \%$ conversion after $150 \mathrm{~min}$. The low deactivation rate might be due to the high consumption of accumulated carbon by $\mathrm{CO}_{2}$ to form $\mathrm{CO}$. Ni/SiO 2 converted feed gas at a slightly lower rate than $\mathrm{Ni}-\mathrm{C} / \mathrm{SiO}_{2}$ at $850^{\circ} \mathrm{C}$; however, the trend was upheld. The promotion effect of $\mathrm{C}$ on $\mathrm{Ni} / \mathrm{SiO}_{2}$ was highly noticeable at $650{ }^{\circ} \mathrm{C}$ and $750{ }^{\circ} \mathrm{C}$. Similar to $\mathrm{CH}_{4}$ conversion, $\mathrm{CO}_{2}$ conversion also maintained a similar trend with slightly high percent conversion, as shown in Figure 2. The reverse water gas shift $\left(\mathrm{H}_{2}+\mathrm{CO}_{2} \rightarrow \mathrm{H}_{2} \mathrm{O}+\mathrm{CO}, \Delta \mathrm{H}=41.1 \mathrm{~kJ} / \mathrm{mol}\right)$ and reverse Boudouard $\left(\mathrm{CO}_{2}+\mathrm{C} \rightarrow 2 \mathrm{CO}\right)$ could be the reason for the high $\mathrm{CO}_{2}$ conversion compared with $\mathrm{CH}_{4}$ conversion. The presence of water in the cold trap during reaction also clearly signposted the occurrence of reverse water-gas shift reaction [21].
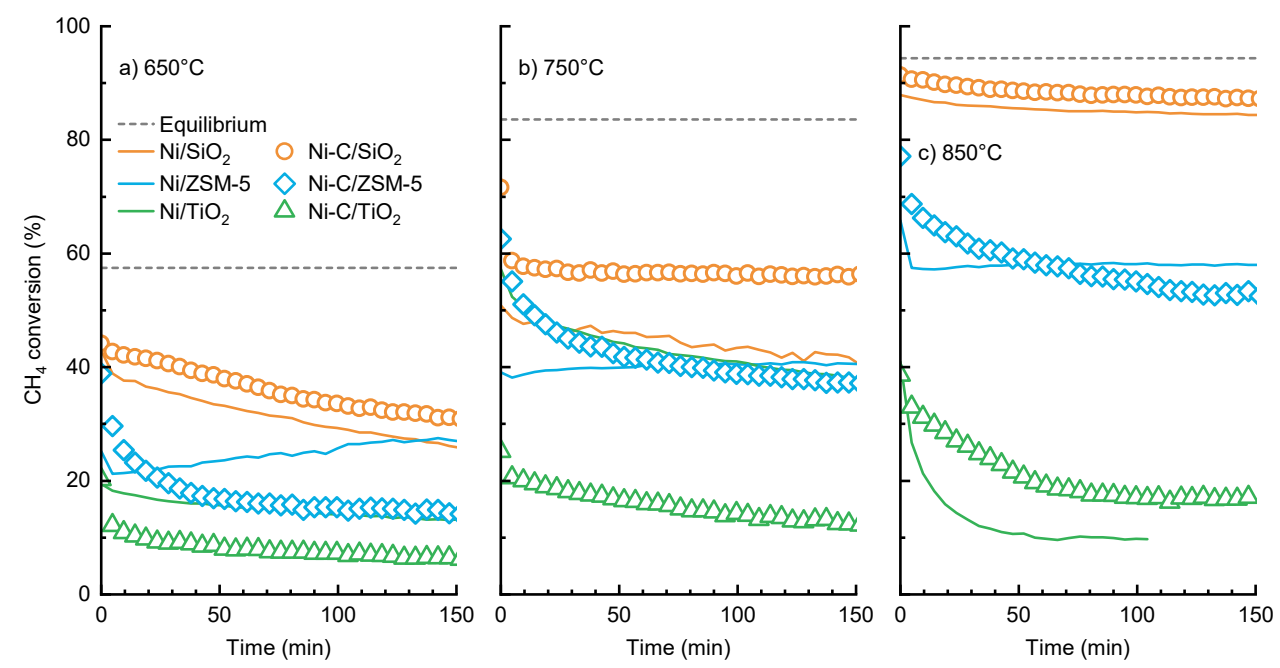

Figure 1. $\mathrm{CH}_{4}$ conversion in DRM (dry reforming of methane) with prepared catalysts at different temperatures. (a) $650{ }^{\circ} \mathrm{C}$, (b) $750{ }^{\circ} \mathrm{C}$, (c) $850{ }^{\circ} \mathrm{C}$
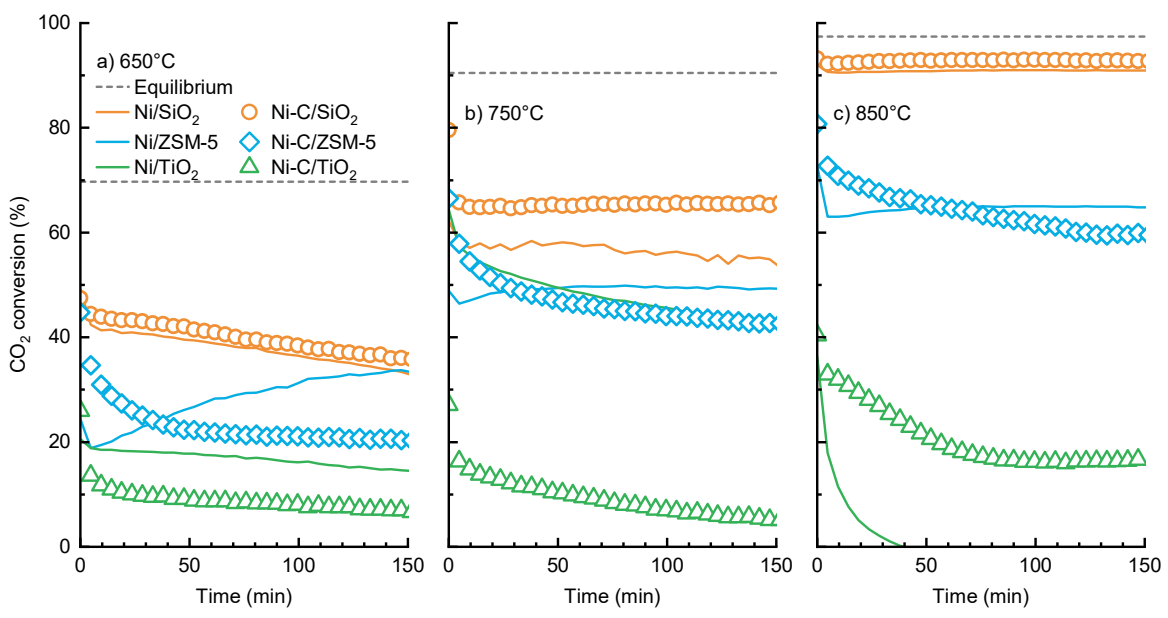

Figure 2. $\mathrm{CO}_{2}$ conversion in DRM with prepared catalysts at different temperatures. (a) $650{ }^{\circ} \mathrm{C}$, (b) $750{ }^{\circ} \mathrm{C}$, (c) $850{ }^{\circ} \mathrm{C}$ 
The downward inclination of the $\mathrm{H}_{2} / \mathrm{CO}$ ratio at low temperature in Figure S3a was due mainly to the occurrence of reverse water-gas shift. This result could be attributed to the endothermic nature of reverse water-gas shift compared with that of DRM $\left(\mathrm{CH}_{4}+\mathrm{CO}_{2} \rightarrow \mathrm{H}_{2}+\mathrm{CO}, \Delta \mathrm{H}=247 \mathrm{~kJ} / \mathrm{mol}\right)$ [22]. High temperature favors a strong endothermic dry reforming reaction. It also favors endothermic $\mathrm{CH}_{4}$ decomposition and exothermic water-gas shift reaction $\left(\mathrm{H}_{2} \mathrm{O}+\mathrm{CO} \rightarrow \mathrm{H}_{2}+\mathrm{CO}_{2}, \Delta \mathrm{H}=-41.1 \mathrm{~kJ} / \mathrm{mol}\right)$ and subsequently increases the amount of $\mathrm{H}_{2}$. The $\mathrm{H}_{2}$ : $\mathrm{CO}$ ratio was always below unity, which confirmed the existence of methane decomposition and Boudouard reactions. However, $\mathrm{Ni}-\mathrm{C} / \mathrm{SiO}_{2}$ catalyst controlled those demoting reactions and maintained an $\mathrm{H}_{2}: \mathrm{CO}$ ratio of 0.8 at $850^{\circ} \mathrm{C}$ (Figure S3c). Irrespective of the declining activity of $\mathrm{Ni} / \mathrm{SiO}_{2}$ catalyst at $650{ }^{\circ} \mathrm{C}$ and $750{ }^{\circ} \mathrm{C}, \mathrm{Ni} / \mathrm{ZSM}-5$ exhibited stable conversion after a slight drop from the initial conversion at all experimented temperatures. This finding could be attributed to the fast balance of production and consumption of carbon deposition. The total carbon balance throughout process was close to 100, which is exhibited in Figure S4. Compared with that of $\mathrm{SiO}_{2}$-supported catalysts, feed conversion was lower for $\mathrm{ZSM}-5$ - and $\mathrm{TiO}_{2}$-supported ones. The addition of $\mathrm{C}$ improved the initial activity of Ni/ZSM-5, but failed to maintain stability and caused fast deactivation. The performance of the $\mathrm{TiO}_{2}$-supported catalyst was poor compared to others considered in this study, and the addition of $\mathrm{C}$ had further decreased the performance of $\mathrm{Ni} / \mathrm{TiO}_{2}$ at 650 and $750{ }^{\circ} \mathrm{C}$ (Figure 2a,b). The catalytic performance of $\mathrm{Ni} / \mathrm{TiO}_{2}$ at $850{ }^{\circ} \mathrm{C}$ was lower than that $750{ }^{\circ} \mathrm{C}$, and this might be attributed to the oxidation of $\mathrm{Ni}$ active sites and the sintering of $\mathrm{Ni}$ particles at high temperature, which happened due to their weak metal-support interaction. The slightly high catalytic performance of $\mathrm{Ni}-\mathrm{C} / \mathrm{TiO}_{2}$ at $850{ }^{\circ} \mathrm{C}$ than that of $\mathrm{Ni} / \mathrm{TiO}_{2}$ might be due to the combined contributions of glucose-derived carbon and the endothermic nature of DRM.

\subsection{Physicochemical Characteristics of the Catalysts}

The reducibility of the developed catalysts, metal-support interaction, and influence of the promoter on metal-support interaction were investigated using $\mathrm{H}_{2}$-TPR (temperature programmed reduction) measurements. The $\mathrm{H}_{2}$-TPR profiles of investigated catalysts are exhibited in Figure 3.

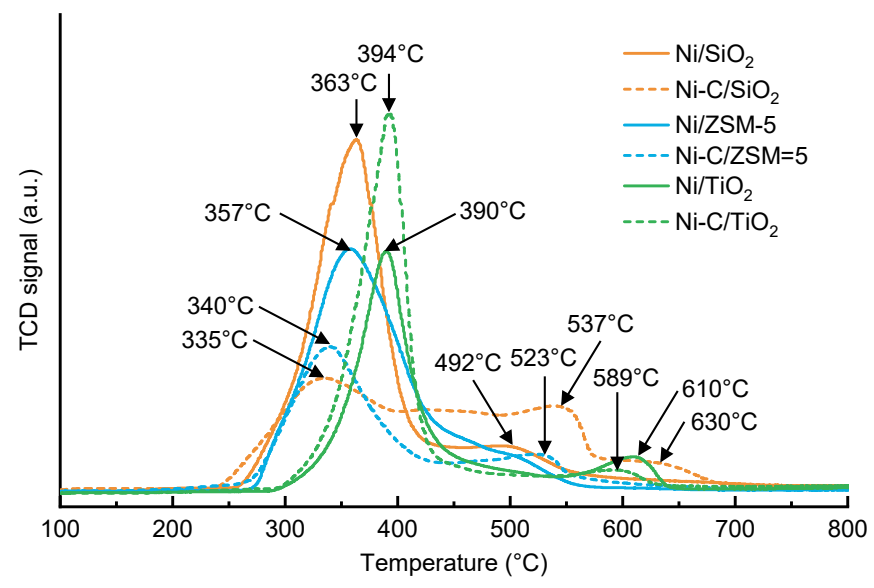

Figure 3. $\mathrm{H}_{2}$-TPR profiles of examined catalysts.

The distinctive effect of doped $\mathrm{C}$ on $\mathrm{NiO}$ reduction and metal-support interaction was indicated by the changes in the TPR profiles. A reduction band in the temperature range of $300-450{ }^{\circ} \mathrm{C}$, typically assigned to the reduction of nickel oxide or $\mathrm{Ni}^{2+}$ species without or with low interaction with the support [23], was exhibited by all investigated catalysts. The reduction of $\mathrm{Ni} / \mathrm{SiO}_{2}$ occurred in two stages. The intense low-temperature hydrogen consumption peak centered at $363^{\circ} \mathrm{C}$ with a shoulder at $342{ }^{\circ} \mathrm{C}$ was attributed to the reduction of weakly or non-interacted $\mathrm{NiO}$ species. The second low intense shoulder peak with a maximum at $492^{\circ} \mathrm{C}$ indicated the reduction of $\mathrm{NiO}$ having intermediate interaction with the support. Earlier studies explicitly support the complete reduction of $\mathrm{Ni} / \mathrm{SiO}_{2}$ between $300^{\circ} \mathrm{C}$ and $600^{\circ} \mathrm{C}$ [24]. The extended second shoulder peak beyond $600^{\circ} \mathrm{C}$ might be attributed 
to the low quantity of $\mathrm{NiO}$ having strong interaction with the support [25]. The presence of $\mathrm{C}$ had a huge effect on the $\mathrm{Ni}-\mathrm{SiO}_{2}$ interaction. $\mathrm{Ni}-\mathrm{C} / \mathrm{SiO}_{2}$ was reduced in three stages. The low-temperature reduction peak shifted to a much low temperature with a maximum at $335^{\circ} \mathrm{C}$ and severely reduced the intensity. Two shoulder peaks, which indicated a strong metal-support interaction, were observed above $500{ }^{\circ} \mathrm{C}$. The low intense high-temperature shoulder peak between $600{ }^{\circ} \mathrm{C}$ and $630{ }^{\circ} \mathrm{C}$ was noted as the highest temperature peak among investigated catalysts, thereby confirming the highest metal-support interaction in $\mathrm{Ni}-\mathrm{C} / \mathrm{SiO}_{2}$. The results explicitly indicated that $\mathrm{Ni}$ species were well dispersed over $\mathrm{SiO}_{2}$ in the presence of $\mathrm{C}$.

The low-temperature broad reduction band of Ni/ZSM- 5 with a peak centered at $357^{\circ} \mathrm{C}$ depicted the presence of Ni-species lightly or not bounded with ZSM- 5 and/or positioned in the supercages, cavities, and/or channels of ZSM-5. The addition of $C$ lowered the intensity of low-temperature peaks. However, a newly generated high-temperature peak with a maximum at $523^{\circ} \mathrm{C}$ vividly portrayed the slightly improved Ni-zeolite interaction. Considering the reduction profiles of $\mathrm{Ni}-\mathrm{C} / \mathrm{SiO}_{2}$ and $\mathrm{Ni}-\mathrm{C} / \mathrm{ZSM}-5$, we could assume that $\mathrm{Ni}$ was supported over the surface of $\mathrm{SiO}_{2}$ and ZSM-5 and on the surface of the promoter $\mathrm{C}$, thereby proving the better metal-support interaction. Among the non-doped catalysts, $\mathrm{Ni} / \mathrm{TiO}_{2}$ showed a high-temperature low-intense reduction peak centered at $610{ }^{\circ} \mathrm{C}$, which could be assigned to the significant interaction of $\mathrm{Ni}^{2+}$ with $\mathrm{TiO}_{2}$. However, the incorporation of $\mathrm{C}$ lowered the intensity of high-temperature reduction peaks and increased the intensity of low-temperature peak centered at $394{ }^{\circ} \mathrm{C}$. This finding revealed the easy reduction and lowered $\mathrm{Ni}-\mathrm{TiO}_{2}$ interaction upon C-addition and could be attributed to the pre-filling of pores of $\mathrm{TiO}_{2}$ with $\mathrm{C}$ during impregnation that caused aggregation of bulk Ni-species over the surface of $\mathrm{TiO}_{2}$. These assumptions were also confirmed by the STEM-EDS elemental scanning results shown later.

The textural properties of all nickel catalysts and bare supports were evaluated by nitrogen adsorption-desorption isotherms. Isotherms are shown in Figure 4, and the physicochemical characteristics obtained from $\mathrm{N}_{2}$ adsorption-desorption isotherms and XRD patterns (Figure 5) are presented in Table 1. The commonly exhibited type II isotherms were presented by Ni-based catalysts following International Union of Pure and Applied Chemistry (IUPAC) classification [26]. However, the different supports exhibiting diverse hysteresis loops might be attributed to the different pore structures.
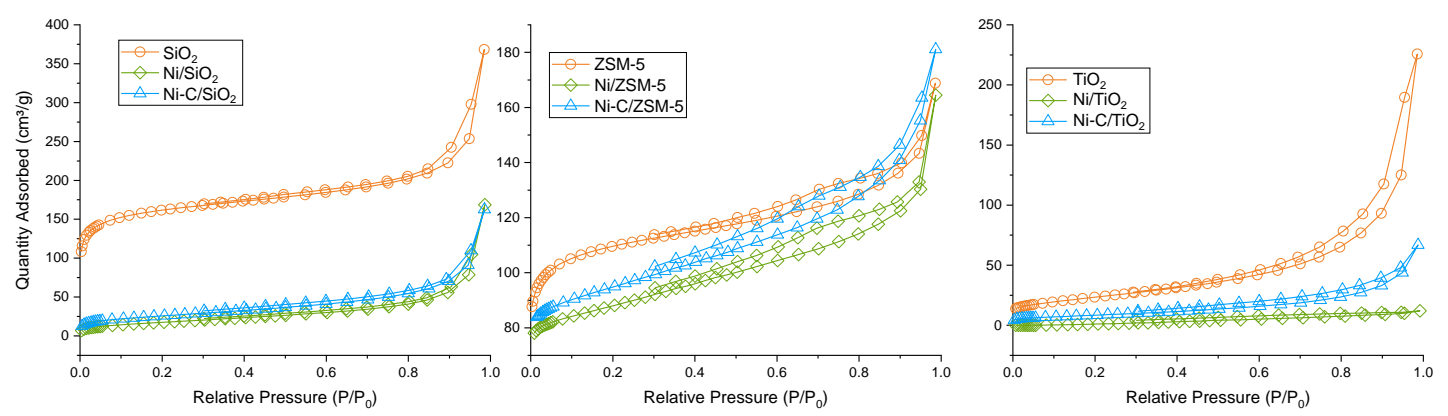

Figure 4. $\mathrm{N}_{2}$ adsorption/desorption isotherms of examined catalysts.

As seen in Figure 4, $\mathrm{SiO}_{2}$ exhibited type II isotherms with an $\mathrm{H} 3-\mathrm{H} 4$ hysteresis loop, thereby indicating a meso-macroporous structure. The sharp increase in adsorption amount from relative pressure $=0.7$ might be attributed to the fairly narrow pore size distributions, which was further confirmed from the pore-size distribution curve in Figure S5. The figure also indicated that the pore size distributions were mainly distributed in a region of $>25 \mathrm{~nm}$ diameter (meso-macroporous-region). Impregnation of $\mathrm{Ni}$ decreased the width of the hysteresis loop to a likely $\mathrm{H} 4$, indicating a decrease in the amount of $\mathrm{N}_{2}$ adsorption. This meant the destruction of the mesoporous structure by the anchored $\mathrm{Ni}$ particles, which resulted in low surface area and total pore volume (Table 1) [27]. In addition, the hysteresis loop indicated a high pore size uniformity, as shown in Figure S5. The addition of C improved the surface area of $\mathrm{Ni} / \mathrm{SiO}_{2}$, which designated the inhibition of Ni-particle agglomeration in 
the presence of $\mathrm{C}$. In short, the doped $\mathrm{C}$ improved the overall surface characteristics and metal-support interaction of $\mathrm{Ni} / \mathrm{SiO}_{2}$ (Table 1). The catalytic performance of $\mathrm{Ni}-\mathrm{C} / \mathrm{SiO}_{2}$ was higher compared with that of $\mathrm{Ni} / \mathrm{SiO}_{2}$ due to its improved surface characteristics, higher dispersion, and metal-support interaction. Similar to $\mathrm{SiO}_{2}, \mathrm{TiO}_{2}$ exhibited type I isotherms with $\mathrm{H} 4$ hysteresis loops. The incorporation of $\mathrm{Ni}$ largely diminished its surface area from $86 \mathrm{~m}^{2} / \mathrm{g}$ to $4 \mathrm{~m}^{2} / \mathrm{g}$, whereas the addition of C improved the surface area to $31 \mathrm{~m}^{2} / \mathrm{g}$. This higher surface area might be attributed to the similar doped C effect in $\mathrm{Ni}-\mathrm{C} / \mathrm{SiO}_{2}$. Figure 4 also shows the isotherms of free ZSM-5, Ni/ZSM-5, and Ni-C/ZSM-5. The isotherm with a high adsorption volume at a relative pressure of 0.1 specifically indicated the existence of the micropores in the zeolites [28]. The rectangular $\mathrm{H} 4$ hysteresis loop identified at a high relative pressure (above 0.5 ) corresponded to the mesopores in the zeolite. The impregnation of $\mathrm{Ni}$ and $\mathrm{Ni}-\mathrm{C}$ eliminated the microporosity, whereas the hysteresis loop was not altered. The impregnation of $\mathrm{Ni}$ reduced the total surface area, whereas pore volume remained intact. Furthermore, the BET surface area of the C-doped Ni/ZSM- 5 was slightly higher than that of the non-doped catalyst, and the former subsequently possessed higher initial catalytic activity than the later.

Table 1. Textural characteristics of the reduced and spent catalysts.

\begin{tabular}{|c|c|c|c|c|c|c|}
\hline \multirow{2}{*}{ Sample } & \multirow{2}{*}{$S_{\text {BET }}\left(\mathrm{m}^{2} / \mathrm{g}\right)$} & \multirow{2}{*}{ Pore Volume $\left(\mathrm{cm}^{3} / \mathrm{g}\right)$} & \multirow{2}{*}{$\begin{array}{l}\text { Average Pore } \\
\text { Diameter (nm) }\end{array}$} & \multicolumn{3}{|c|}{ Crystal Size (nm) } \\
\hline & & & & Fresh & DRM-650 & DRM-850 \\
\hline $\mathrm{SiO}_{2}$ & 463 & 0.57 & 3.80 & - & - & - \\
\hline $\mathrm{Ni} / \mathrm{SiO}_{2}$ & 65 & 0.26 & 3.06 & $\begin{array}{l}33.5 \star \\
16.9 \star\end{array}$ & $\begin{array}{l}27.4^{\text {公 }} \\
15.2^{\star}\end{array}$ & $\begin{array}{l}26.6^{\text {t }} \\
23.3^{\star}\end{array}$ \\
\hline $\mathrm{Ni}-\mathrm{C} / \mathrm{SiO}_{2}$ & 92 & 0.25 & 3.42 & $\begin{array}{l}6.4^{\star} \\
-\star\end{array}$ & $7.2^{-\frac{1}{4}}$ & $\begin{array}{l}7.6 \\
7.0 \star\end{array}$ \\
\hline ZSM-5 & 361 & 0.26 & 3.83 & - & - & - \\
\hline Ni/ZSM-5 & 288 & 0.25 & 3.43 & $\begin{array}{l}22.8 \\
14.5\end{array}$ & $\begin{array}{l}24.4^{\text {文 }} \\
14.2^{\star}\end{array}$ & $\begin{array}{l}22.9^{\text {t }} \\
16.9^{\star}\end{array}$ \\
\hline Ni-C/ZSM-5 & 311 & 0.28 & 3.07 & $\begin{array}{l}26.9 \star \\
16.9 \star\end{array}$ & $\begin{array}{l}31.6 \text { 文 } \\
14.4^{\star}\end{array}$ & $\begin{array}{l}24.6 \text { 类 } \\
22.7 \star\end{array}$ \\
\hline $\mathrm{TiO}_{2}$ & 86 & 0.35 & 3.39 & - & - & - \\
\hline $\mathrm{Ni} / \mathrm{TiO}_{2}$ & 4 & 0.19 & 3.05 & $\begin{array}{l}23.8 \\
15.7\end{array}$ & $\begin{array}{c}29.5 \text { 放 } \\
-\star\end{array}$ & $\begin{array}{c}30.3^{\text {放 }} \\
-\star\end{array}$ \\
\hline $\mathrm{Ni}-\mathrm{C} / \mathrm{TiO}_{2}$ & 31 & 0.11 & 3.07 & $\begin{array}{c}34.2 \star \\
-\star\end{array}$ & $\begin{array}{l}29.1 \text { 㐬 } \\
-\star\end{array}$ & $\begin{array}{l}30.7 \text { 就 } \\
-\star\end{array}$ \\
\hline
\end{tabular}

based on the $\mathrm{Ni}^{0}$ diffraction peak. ${ }^{\star}$ based on $\mathrm{NiO}$ diffraction peak. DRM: dry reforming of methane.

The crystalline structure of catalysts, the size of Ni particles, and their alteration upon DRM were clarified from X-ray diffraction patterns. Figure 5 depicts the recorded XRD patterns. Average Ni crystallite size was estimated from diffraction peaks at $2 \theta=44.6^{\circ}, 51.9^{\circ}$, and $76.8^{\circ}$. The addition of $\mathrm{C}$ to $\mathrm{Ni} / \mathrm{SiO}_{2}$ reduced its average Ni-crystallite size from $33.52 \mathrm{~nm}$ to $16.89 \mathrm{~nm}$, thereby indicating that $\mathrm{C}$ promoted the widespread dispersion of $\mathrm{Ni}$ over $\mathrm{SiO}_{2}$. These results were consistent with the findings in pore structure and $\mathrm{H}_{2}$-TPR analyses. Slightly intense $\mathrm{NiO}$ phases were found in $\mathrm{Ni} / \mathrm{SiO}_{2}$ diffraction pattern as identified by the peaks centered at $2 \theta=37.4^{\circ}, 43.5^{\circ}$, and $63.2^{\circ}$, designating small quantity of incompletely reduced $\mathrm{NiO}$ at $8500^{\circ} \mathrm{C}$. This finding was supported by the extended shoulder peak of $\mathrm{Ni} / \mathrm{SiO}_{2}$ in the TPR profile (Figure 3). However, $\mathrm{NiO}$ diffraction peaks were not found in the $\mathrm{Ni}-\mathrm{C} / \mathrm{SiO}_{2}$ diffraction pattern. It might be because of an easy $\mathrm{NiO}$ reduction or its high dispersion in the presence of glucose, rendering the XRD detection difficult. At the same time, the reappearance of $\mathrm{NiO}$ peaks upon DRM at $850{ }^{\circ} \mathrm{C}$ indicated the agglomeration of highly dispersed $\mathrm{NiO}$ and enabled its XRD detection. The high degree of Ni-dispersion in the presence of $\mathrm{C}$ resulted in the high initial activity of $\mathrm{Ni}-\mathrm{C} / \mathrm{SiO}_{2}$ (Figures 1 and 2). The less intense $\mathrm{XRD}$ peaks observed with $\mathrm{Ni}-\mathrm{C} / \mathrm{SiO}_{2}$ might be attributed to low crystallinity and good dispersion upon $\mathrm{C}$ addition. The comparable Ni-crystallite sizes in Table 1 before and after DRM clearly eliminated the possibility of particle agglomeration at the high-temperature reaction. Thus, catalyst deactivation owing to particle agglomeration could be excluded. Furthermore, a noticeable graphitic carbon peak could be found after DRM at $650{ }^{\circ} \mathrm{C}$ (as seen in peaks centered at $2 \theta=26.4^{\circ}$ ). The fast catalyst deactivation of $\mathrm{Ni}$ supported over $\mathrm{SiO}_{2}$ 
could be attributed to this high carbon deposit (Figure 1). Thus, the deposition of carbon atoms either destabilized the adsorption capacity of clean active catalyst phases or hindered it from reacting with feed gases. However, the peaks for carbon were absent after DRM at $850{ }^{\circ} \mathrm{C}$ due to very low or negligible carbon deposition. In addition to the diffraction peaks that corresponded to Ni-phases, the diffraction peaks corresponded to the $\mathrm{NiO}$ phases became evident after $\mathrm{DRM}$ for $\mathrm{Ni} / \mathrm{SiO}_{2}$ and $\mathrm{Ni}-\mathrm{C} / \mathrm{SiO}_{2}$, especially at $850^{\circ} \mathrm{C}$. This result indicated the existence of non-reduced $\mathrm{NiO}$ phases even after reaction or reoxidization at the high temperature. The $\mathrm{H}_{2}$-TPR and XRD results concisely validated the high activity and stability of $\mathrm{Ni}-\mathrm{C} / \mathrm{SiO}_{2}$ at high temperatures during the entire analysis (Figures 1 and 2). Compared to $\mathrm{Ni} / \mathrm{SiO}_{2}, \mathrm{Ni} / \mathrm{ZSM}-5$ presented fairly similar diffraction peaks in the presence of added $\mathrm{C}$. By contrast, the diffraction intensity of $\mathrm{Ni} / \mathrm{TiO}_{2}$ was reduced upon $\mathrm{C}$-addition. Furthermore, $\mathrm{NiO}$ and/or $\mathrm{Ni}$ crystal sizes were increased after $\mathrm{C}$-addition, thereby indicating the low effect of $\mathrm{C}$ on Ni-dispersion in ZSM- 5 and $\mathrm{TiO}_{2}$ supports. The presence of $\mathrm{NiO}$ peaks in Ni/ZSM- 5 samples after reduction at $850{ }^{\circ} \mathrm{C}$ might be attributed to the difficulty in reducing the deeply placed Ni-particles at internal cavities of ZSM-5. Furthermore, the comparable $\mathrm{H}_{2}$-TPR profiles and XRD patterns of ZSM-5 supported samples indicated the neutral influence of $\mathrm{C}$ on Ni/ZSM-5. These results revealed that $\mathrm{C}$ played an inverse effect on the characteristics of $\mathrm{Ni} / \mathrm{TiO}_{2}$. The neutral and negative influences of $\mathrm{C}$ on the physicochemical characteristics of Ni/ZSM- 5 and $\mathrm{Ni} / \mathrm{TiO}_{2}$ were evident in the similar and low catalytic performance of Ni-C/ZSM- 5 and $\mathrm{Ni}-\mathrm{C} / \mathrm{TiO}_{2}$ (Figures 1 and 2), respectively. The higher initial catalytic activity of Ni-C/ZSM- 5 than that of Ni/ZSM- 5 might be attributed to the slightly high $\mathrm{Ni}$ dispersion in the presence of $\mathrm{C}$, which was confirmed by the slightly less intense XRD peaks and $\mathrm{H}_{2}$-TPR profile.
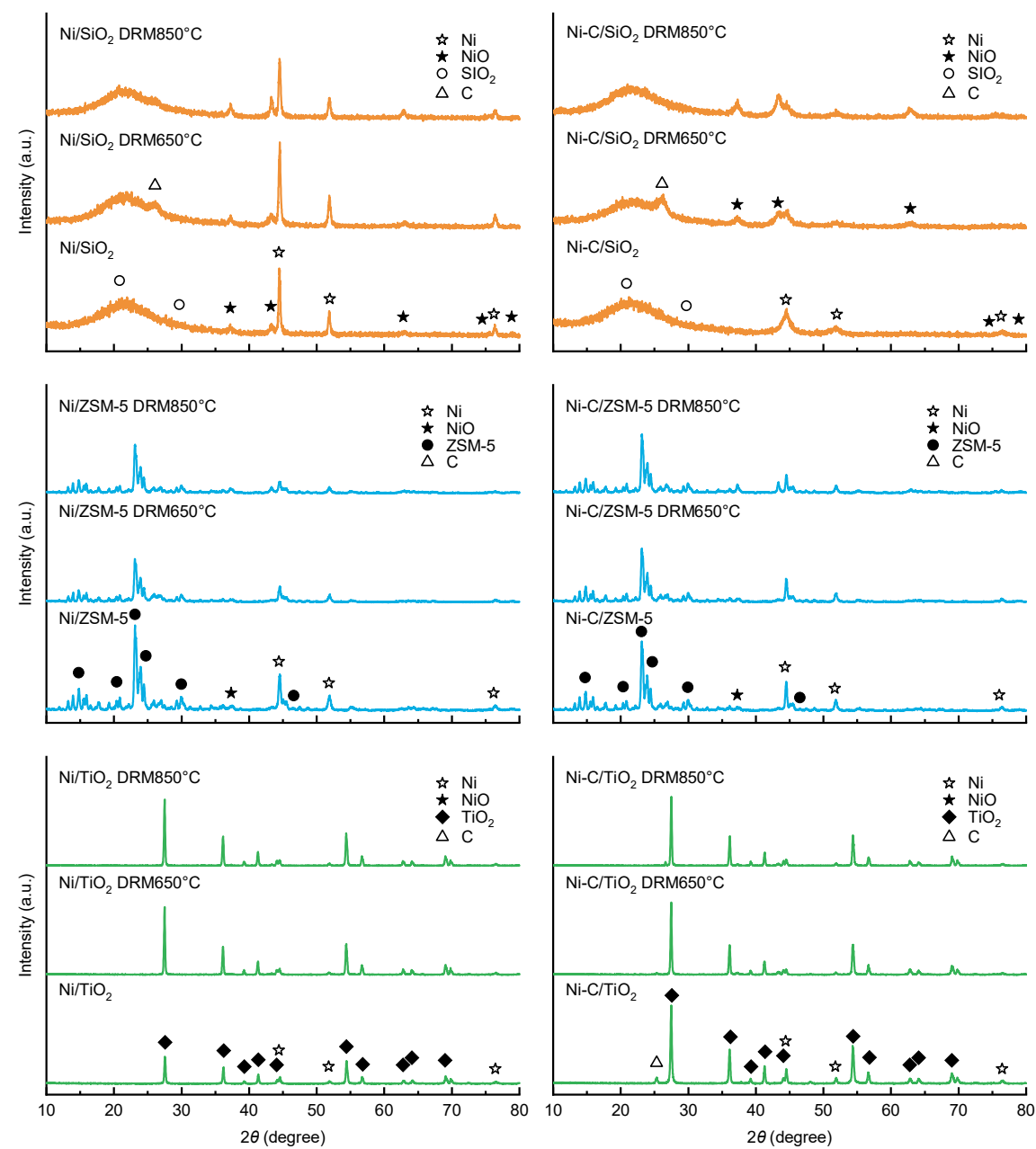

Figure 5. XRD diffraction patterns of examined catalysts. 
EXAFS analyses were conducted to confirm the characteristics of catalysts before and after DRM. EXAFS profiles are shown in Figure 6. The EXAFS profile of $\mathrm{Ni}-\mathrm{C} / \mathrm{SiO}_{2}$ clearly followed the Ni-foil profile, thereby indicating complete reduction as confirmed with XRD patterns in Figure 5. However, $\mathrm{Ni} / \mathrm{SiO}_{2}$ analogous to $\mathrm{Ni}$-foil was attributed to the presence of non-reduced $\mathrm{NiO}$ phases. In addition, $\mathrm{NiO}$ peaks became prominent after DRM. The declined intensity was credited to the abridged size of the supported Ni particle. The EXAFS patterns of Ni-catalysts supported over ZSM-5 and $\mathrm{TiO}_{2}$ also clearly supported the described $\mathrm{H}_{2}$-TPR and XRD results.
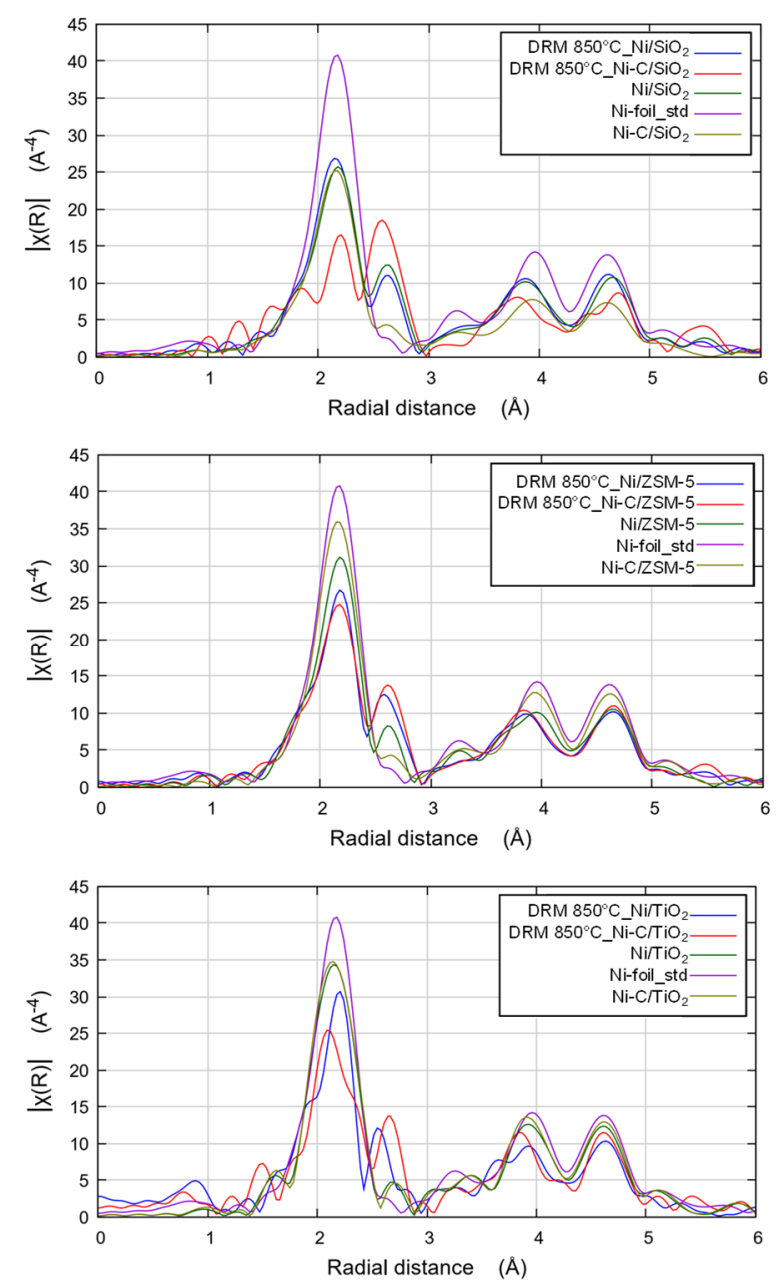

Figure 6. EXAFS profiles of examined catalysts before and after DRM at $850{ }^{\circ} \mathrm{C}$.

Given that XRD confirmed the existence of produced carbon after DRM, the nature and stability of as-produced carbon were confirmed with TGA (thermogravimetric analysis) under an air atmosphere. TGA traces of catalysts before and after DRM at $650{ }^{\circ} \mathrm{C}$ and $850{ }^{\circ} \mathrm{C}$ are shown in Figure S6. In general, the weight loss of fresh non-doped catalysts below $500{ }^{\circ} \mathrm{C}$ was attributed to the desorption of binder gas vapors inside the pores. The successive weight gain was due to oxidation of reduced $\mathrm{Ni}$ to $\mathrm{NiO}$ in the presence of $\mathrm{O}_{2}$. However, the weight loss exhibited by the C-supported catalyst after $500{ }^{\circ} \mathrm{C}$ was due to the removal of $\mathrm{C}$ with $\mathrm{O}_{2}$. The less intense $\mathrm{C}$-removal of $\mathrm{Ni}-\mathrm{C} / \mathrm{SiO}_{2}$ indicated its higher interaction with the materials compared with that of Ni-C/ZSM-5, thereby supporting XRD and TPR results. Similarly, the spent catalysts exhibited similar weight loss after $500{ }^{\circ} \mathrm{C}$ based on the extent of C-deposition during DRM. The least weight loss was exhibited by the spent catalyst at $850{ }^{\circ} \mathrm{C}$, as shown in Figure 7, pointing out its low C-deposit, which was in good agreement with previously discussed results. The removal of deposited $C$ together with in-situ present $C$ in catalysts might be the reason for their high weight loss observed with $\mathrm{C}$-doped catalysts. The TGA results explicitly proved 
that $\mathrm{C}$-doping did not improve the $\mathrm{C}$-deposition resistance of $\mathrm{Ni} / \mathrm{SiO}_{2}$, but enhanced its stability and activity. Irrespective of the behavior of the $\mathrm{SiO}_{2}$ - and $\mathrm{ZSM}-5$-supported catalysts, the spent $\mathrm{Ni} / \mathrm{TiO}_{2}$ showed a weight gain that indicated $\mathrm{Ni}$ oxidation and no carbon deposition. These results effectively validated the XRD results.

Figure 8 reveals that the addition of glucose effectively eliminated the Ni-agglomeration tendency. The bright spots in Figure 8a indicate the agglomerated Ni-species, whereas such agglomerations are absent in Figure 8b, exhibiting a homogeneous distribution of Ni. These phenomena resulted in high catalytic performance (Figures 1 and 2). However, the incorporation of $C$ in Ni/ZSM-5 catalyst did not significantly change the Ni-agglomeration (Figure S7), thereby reflecting the similar catalytic performance of Ni/ZSM- 5 and Ni-C/ZSM- 5 catalysts. Different from the effect of glucose on $\mathrm{Ni} / \mathrm{SiO}_{2}$ and $\mathrm{Ni} / \mathrm{ZSM}-5$, extensive agglomeration occurred for $\mathrm{Ni} / \mathrm{TiO}_{2}$ and resulted in fast deactivation during DRM. This finding might be attributed to the strong interaction between $\mathrm{C}$ and $\mathrm{TiO}_{2}$, which consecutively resulted in high Ni-aggregation.

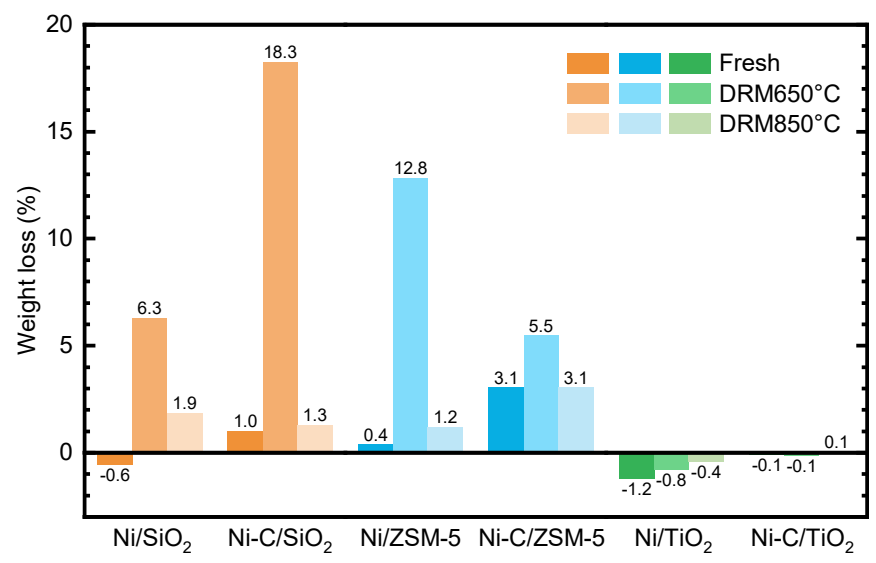

Figure 7. Weight loss calculated from TGA trace.
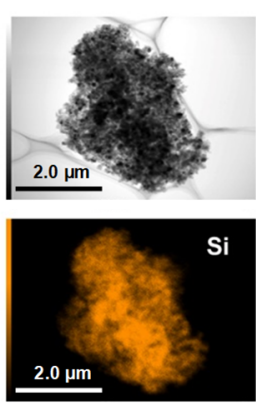

$\mathrm{Si}$

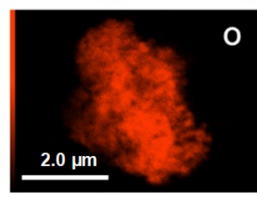

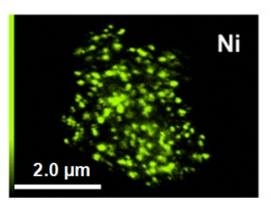
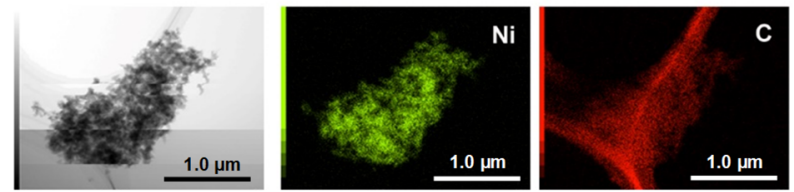

b)
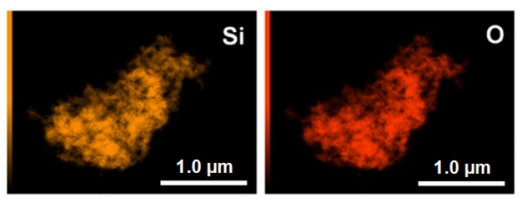

Figure 8. TEM-EDS elemental mapping images of fresh catalysts: (a) $\mathrm{Ni} / \mathrm{SiO}_{2}$ and (b) $\mathrm{Ni}-\mathrm{C} / \mathrm{SiO}_{2}$.

\subsection{Stability Test}

Stability tests were conducted for $\mathrm{Ni} / \mathrm{SiO}_{2}$ and $\mathrm{Ni}-\mathrm{C} / \mathrm{SiO}_{2}$ at $750{ }^{\circ} \mathrm{C} . \mathrm{CH}_{4}$ and $\mathrm{CO}_{2}$ conversions are exhibited in Figure 9. 

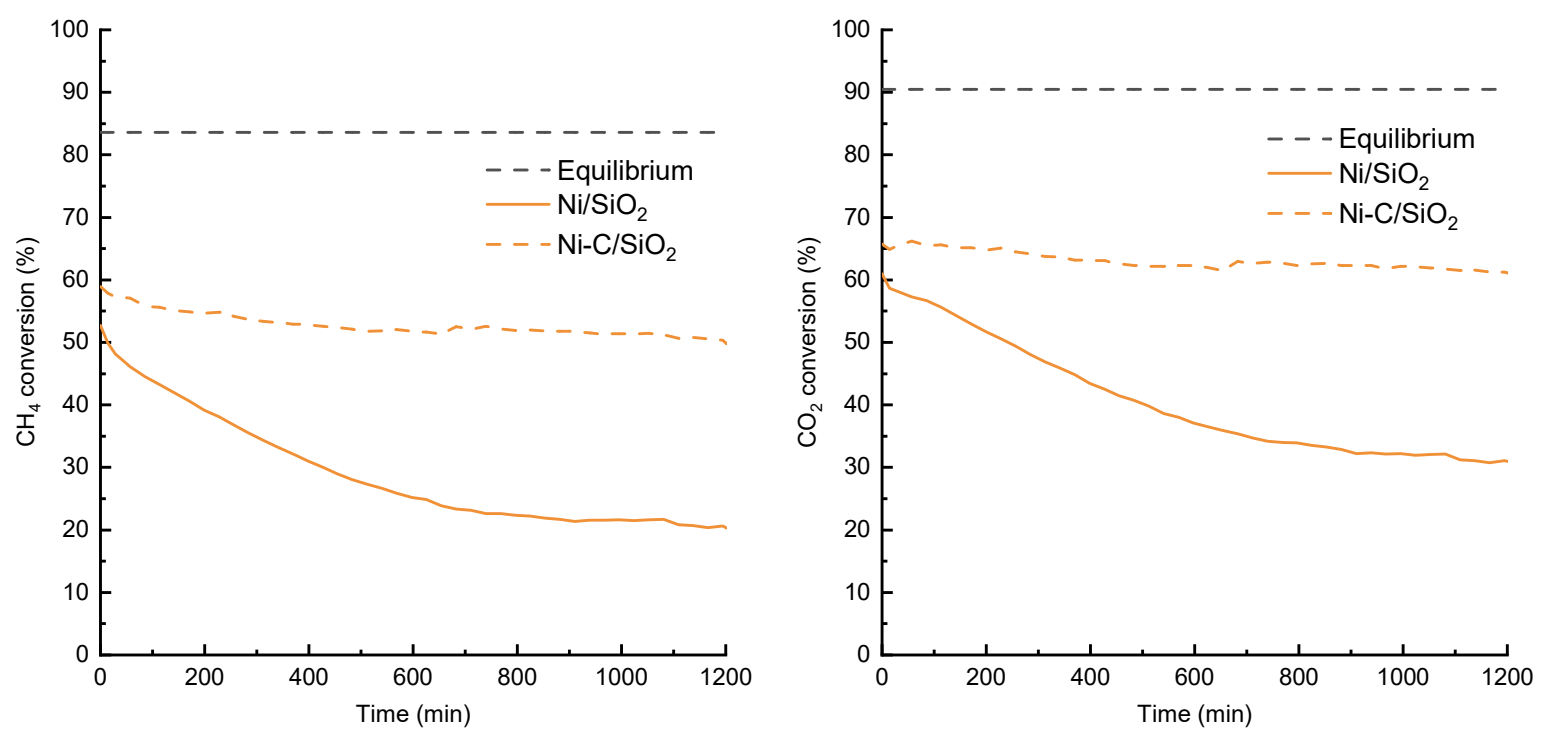

Figure 9. $\mathrm{CH}_{4}$ and $\mathrm{CO}_{2}$ conversion during the stability test of $\mathrm{Ni} / \mathrm{SiO}_{2}$ and $\mathrm{Ni}-\mathrm{C} / \mathrm{SiO}_{2}$ at $750{ }^{\circ} \mathrm{C}$.

A huge deactivation was exhibited by $\mathrm{Ni} / \mathrm{SiO}_{2}$ during the test time of $20 \mathrm{~h}$. However, greater stability was given by $\mathrm{Ni}-\mathrm{C} / \mathrm{SiO}_{2}$ in similar experimental conditions with a drop of $8 \%$ from an initial $\mathrm{CH}_{4}$ conversion of $59 \%$. Contrary to previous research results, carbon deposition was not a reason for the slight or high deactivation of $\mathrm{Ni}-\mathrm{C} / \mathrm{SiO}_{2}$ or $\mathrm{Ni} / \mathrm{SiO}_{2}$, respectively, at $750{ }^{\circ} \mathrm{C}$. Thus, no significant carbon deposition was observed in elemental mapping, as shown in Figure 9. These results were further confirmed by TGA results (Figure S8). Hence, the observations concluded that the most of carbon species produced over Ni-based catalysts at $750{ }^{\circ} \mathrm{C}$ and $850{ }^{\circ} \mathrm{C}$ were active and readily reacted with $\mathrm{CO}_{2}$ to produce $\mathrm{CO}$. The high deactivation of $\mathrm{Ni} / \mathrm{SiO}_{2}$ could be attributed to the Ni-particle agglomeration at high temperatures. Heavy Ni aggregations are shown in Figure 10a. The minor deactivation of $\mathrm{Ni}-\mathrm{C} / \mathrm{SiO}_{2}$ might be attributed to the slight Ni-sintering upon the gradual removal of glucose-derived carbon under the $\mathrm{CH}_{4}-\mathrm{CO}_{2}$ stream at $750{ }^{\circ} \mathrm{C}$.
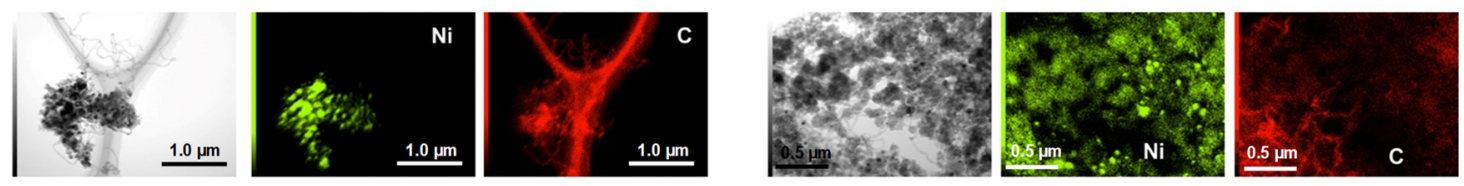

a)
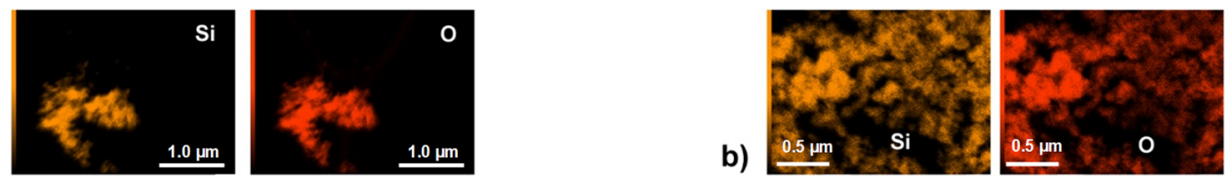

Figure 10. STEM-EDS elemental mapping images of catalysts after stability test at $850{ }^{\circ} \mathrm{C}:(a) \mathrm{Ni} / \mathrm{SiO}_{2}$, and $(\mathbf{b}) \mathrm{Ni}-\mathrm{C} / \mathrm{SiO}_{2}$.

\section{Materials and Methods}

\subsection{Catalyst Preparation}

Analytical grade chemicals were used for catalyst synthesis. The support $\mathrm{SiO}_{2}$ (nanopowder, 5-15 nm particle size) and $\mathrm{TiO}_{2}$ anatase (nanopowder, $<25 \mathrm{~nm}$ particle size) were purchased from Aldrich (St. Louis, MO, USA) and ZSM-5 (CBV 3024E) from Zeolyst International (Kansas, MO, USA). Specific surface characteristics of supports are given in Table 1. D-(+)glucose and Ni precursor $\mathrm{Ni}\left(\mathrm{NO}_{3}\right)_{2} \cdot 6 \mathrm{H}_{2} \mathrm{O}$ were purchased from Wako (Osaka, Japan). Ni-supported catalysts were synthesized by a general impregnation method, and their $\mathrm{C}$-doped samples were prepared in a similar manner with glucose as the precursor. In brief, $0.004 \mathrm{~mol} \mathrm{Ni}\left(\mathrm{NO}_{3}\right)_{2} \cdot 6 \mathrm{H}_{2} \mathrm{O}$ was dissolved in $25 \mathrm{~mL}$ of deionized 
water and added to a solution of $0.04 \mathrm{~mol}$ support (2.5 $\mathrm{g}$ ZSM-5, in specific) that was dispersed in $40 \mathrm{~mL}$ of deionized water. The solution was stirred for $2 \mathrm{~h}$ at room temperature, and then water was removed using a rotary evaporator operated for $4 \mathrm{~h}$ at $65^{\circ} \mathrm{C}$. After evaporation, the samples were air-dried overnight at $100{ }^{\circ} \mathrm{C}$ and calcined at $850{ }^{\circ} \mathrm{C}$ for $5 \mathrm{~h}$ under air. The prepared samples were denoted as $\mathrm{Ni} / \mathrm{SiO}_{2}, \mathrm{Ni} / \mathrm{ZSM}-5$, and $\mathrm{Ni} / \mathrm{TiO}_{2}$. For the $\mathrm{C}$-doped catalysts, 0.004 mol glucose was added to the solution in the impregnation, and the dried sample was heated under $\mathrm{N}_{2}$ flow at $850{ }^{\circ} \mathrm{C}$ for $5 \mathrm{~h}$. $\mathrm{C}$-doped catalysts were named $\mathrm{Ni}-\mathrm{C} / \mathrm{SiO}_{2}, \mathrm{Ni}-\mathrm{C} / \mathrm{ZSM}-5$, and $\mathrm{Ni}-\mathrm{C} / \mathrm{TiO}{ }_{2}$.

\subsection{Dry Reforming of Methane}

The as-synthesized catalysts were initially pelletized and crushed to a size range of 150-212 $\mu \mathrm{m}$ to avoid the possibility of diffusion resistance during DRM. The $100 \mathrm{mg}$ of crushed catalyst was mixed with $200 \mathrm{mg}$ of quartz sand (150-212 $\mu \mathrm{m})$. The quartz sand was used to maintain a uniform catalyst bed temperature and excludes heat and mass transport limitations. The catalytic performance was examined in a fixed bed quartz reactor (i.d. $8 \mathrm{~mm}$ ). The mixed catalyst sample was loaded and packed in the reactor using two quartz wool plugs. A thermocouple (K Class 2 sheathed with SUS316) was loaded inside the quartz reactor to have contact with the catalyst bed. The metallic contents in the thermocouple were not contributed to DRM catalysis, which was confirmed via blank experiments. The quartz reactor was placed in a three-zone heating furnace. Kofloc mass flow controllers were used to control the gas flow rate. The reactor was flushed with $\mathrm{N}_{2}(100 \mathrm{~mL} / \mathrm{min})$ and heated to $850{ }^{\circ} \mathrm{C}$ with a ramp of $10^{\circ} \mathrm{C} / \mathrm{min}$ under $\mathrm{N}_{2}$ flow. $\mathrm{N}_{2}$ stream was replaced by $45 \% \mathrm{H}_{2}$ balanced with $\mathrm{N}_{2}$ to reduce the calcined catalyst sample for $2 \mathrm{~h}$ at $850{ }^{\circ} \mathrm{C}$. The reactor was then cleaned thoroughly with $\mathrm{N}_{2}$ flush after reduction and heated/cooled to the temperature of the DRM test. $\mathrm{N}_{2}$ was replaced by a reactant stream $\left(25 \% \mathrm{CH}_{4}-25 \% \mathrm{CO}_{2}-50 \% \mathrm{~N}_{2}\right)$ with a flow rate that corresponded to a space velocity of $8570 \mathrm{~h}^{-1}$. Activity tests were conducted at $650{ }^{\circ} \mathrm{C}, 750^{\circ} \mathrm{C}$, and $850^{\circ} \mathrm{C}$ for $150 \mathrm{~min}$. Long term stability tests for $20 \mathrm{~h}$ were conducted for selected catalysts at $750{ }^{\circ} \mathrm{C}$. All the effluents were analyzed online with Agilent 490 micro- Gas Chromatography (Santa Clara, CA, USA) equipped with a thermal conductivity detector. Two sets of ice traps were used to remove water vapors produced by reverse water-gas shift reaction before entering to micro-GC.

\subsection{Characterization}

The textural parameters of synthesized catalysts were examined by measurement of $\mathrm{N}_{2}$ adsorption-desorption isotherms using a Quantachrome Nova 3200e at $-196{ }^{\circ} \mathrm{C}$. Samples were degassed at $300{ }^{\circ} \mathrm{C}$ for $5 \mathrm{~h}$ prior to the measurement. The specific surface areas were calculated according to the BET method, whereas the pore size distributions and pore volume were derived from the $\mathrm{BJH}$ method using the desorption branch of the isotherms. A scanning electron microscopy (STEM) observation was performed with a JEOL (Tokyo, Japan), JEM-2100F, with an accelerating voltage of $200 \mathrm{kV}$. Energy-dispersive X-ray spectrometry (EDS) mapping was performed with a JEOL, JED-2300T analyzer. The sample was initially crushed, ground, and dispersed in ethanol under $30 \mathrm{~min}$ ultrasonic agitation. A drop of the suspension was then transferred to a carbon-coated $\mathrm{Cu}$ mesh grid and dried at room temperature for STEM-EDS observation. Rigaku TTR-III X-ray diffractometer instrument (Tokyo, Japan) was used to record the XRD patterns of reduced catalysts before and after DRM tests. The intensity was measured by step scanning in the $2 \theta$ range of $5-80^{\circ}$ with a step of $0.02^{\circ}$ and a scan rate of $0.016^{\circ} \mathrm{s}$. The average crystallite size was calculated with the Scherrer equation.

Temperature-programmed reduction $\left(\mathrm{H}_{2}-\mathrm{TPR}\right)$ measurements were conducted using a Micromeritics TPR 2720 analyzer (Norcross, GA, USA). In brief, a total of $0.05 \mathrm{~g}$ of catalyst was placed in a U-tube holder and cleaned at $550{ }^{\circ} \mathrm{C}$ for $60 \mathrm{~min}$ by flushing with helium gas. After cooling to room temperature, the reductive gas mixture, which comprised of $5 \%$ hydrogen and $95 \%$ nitrogen at a flow rate of $20 \mathrm{~mL} / \mathrm{min}$, was streamed through the sample, and then the catalyst bed was heated up to $800^{\circ} \mathrm{C}$ with a heating rate of $10^{\circ} \mathrm{C} / \mathrm{min}$ to obtain the TPR profiles. Extended X-ray absorption 
fine structure (EXAFS) measurements were conducted at a Beamline (SAGA-LS/BL-06) of Kyushu Synchrotron Light Research Center, Japan.

The quantification of accumulated carbon was conducted by the thermogravimetric analyzer (TGA) using a Hitachi STA 7200 (Tokyo, Japan). The fresh and spent catalysts (5 mg) were heated from 100 to $850^{\circ} \mathrm{C}$ with a heating rate of $10^{\circ} \mathrm{C} / \mathrm{min}$ in air atmosphere. Total weight loss was estimated according to a reported method [29].

\section{Conclusions}

In this research, we investigated the catalytic characteristics of Ni-based catalysts in DRM and the impact of C-doping on their catalytic performance. $\mathrm{SiO}_{2}, \mathrm{ZSM}-5$, and $\mathrm{TiO}_{2}$-supported Ni-catalysts were synthesized and modified with doping of glucose-derived. $\mathrm{Ni}-\mathrm{C} / \mathrm{SiO}_{2}$ presented the highest catalytic performance in DRM to produce syngas. The characterization results confirmed the efficient incorporation of $\mathrm{Ni}$ into the pores of $\mathrm{SiO}_{2}$ in the presence of $\mathrm{C}$, which provided better surface area, smaller particle size, and pore size distribution to $\mathrm{Ni} / \mathrm{SiO}_{2}$. The improved characteristics enabled an enhanced catalytic performance with no or less carbon deposition at high temperatures (e.g., $850{ }^{\circ} \mathrm{C}$ ). The increased reduction temperature of $\mathrm{Ni}-\mathrm{C} / \mathrm{SiO}_{2}$ in the TPR profile signposted the strong Ni interaction with $\mathrm{SiO}_{2}$ in the presence of $\mathrm{C}$, which was superior to all other investigated catalysts. Hence, this result proved that low-cost carbon derived from glucose could enhance $\mathrm{Ni}$-dispersion in $\mathrm{SiO}_{2}$ even without doping of promoter metals. However, no significant improvement in the Ni-dispersion was observed with ZSM-5 support in the presence of doped $\mathrm{C}$. The $\mathrm{C}$-doping to $\mathrm{Ni} / \mathrm{TiO}_{2}$ resulted in larger Ni particle size, low Ni-dispersion, and weak metal-support interaction. The stability and resistance to C-accumulation capability exhibited by $\mathrm{Ni}-\mathrm{C} / \mathrm{SiO}_{2}$ during stability test implied its capability to be a potential candidate for commercial dry reforming of methane application to produce syngas and hydrogen.

Supplementary Materials: The following are available online at http://www.mdpi.com/2073-4344/10/1/21/s1, Figure S1: $\mathrm{H}_{2}$ yield at (a) $650{ }^{\circ} \mathrm{C}$, (b) $750{ }^{\circ} \mathrm{C}$, and (c) $850{ }^{\circ} \mathrm{C}$, Figure S2: CO yield at (a) $650{ }^{\circ} \mathrm{C}$, (b) $750{ }^{\circ} \mathrm{C}$, and (c) $850{ }^{\circ} \mathrm{C}$, Figure $\mathrm{S} 3: \mathrm{H}_{2}: \mathrm{CO}$ ratio at (a) $650{ }^{\circ} \mathrm{C}$, (b) $750{ }^{\circ} \mathrm{C}$, and (c) $850^{\circ} \mathrm{C}$, Figure S4: Carbon balance at (a) $650{ }^{\circ} \mathrm{C}$, (b) $750{ }^{\circ} \mathrm{C}$, and (c) $850{ }^{\circ} \mathrm{C}$, Figure S5: $\mathrm{BJH}$ pore size distributions (a) $\mathrm{SiO}_{2}$, (b) ZSM-5, and (c) $\mathrm{TiO}_{2}$-supported Ni-catalysts, Figure S6: TGA profile of catalysts before and after DRM. (a) Ni/SiO 2 , (b) $\mathrm{Ni}-\mathrm{C} / \mathrm{SiO}_{2}$, (c) Ni/ZSM-5, (d) Ni-C/ZSM-5, (e) Ni/TiO , and (f) $\mathrm{Ni}-\mathrm{C} / \mathrm{TiO}_{2}$, Figure S7: STEM-EDX images and elemental distribution of catalysts before DRM, Figure S8: Comparison of weight loss (\%) calculated from TGA trace.

Author Contributions: Conceptualization, U.A.; methodology, U.A., E.H., J.-i.H.; characterization, U.A., S.A., S.K.; investigation, U.A., S.K., E.H., J.-i.H.; writing—original draft preparation, U.A., S.A.; writing-review and editing, S.K., D.P.M., S.A., E.H., J.-i.H.; supervision, J.-i.H.; funding acquisition, S.K., J.-i.H. All authors have read and agreed to the published version of the manuscript.

Funding: This work was supported by the Japan Society for the Promotion of Science (JSPS) for a Challenging Research (Pioneering) (17H06225). The authors are grateful to the Cooperative Research Program of the Network Joint Research Center for Materials and Devices that have been supported by the Ministry of Education, Culture, Sports, Science, and Technology (MEXT), Japan.

Acknowledgments: Authors would like to thank Yasuyo HACHIYAMA, Asuka MORI, and Kentaro SHIMA for their technical support. The administrative support from Naoko SUDO is highly appreciated. UPMA specially thank Ni'mah Ayu LESTARI and Nurulhuda HALIM for their support in TGA characterization.

Conflicts of Interest: The authors state no conflict of interest.

\section{References}

1. NASA. NOAA Data Show 2016 Warmest Year on Record Globally; NASA: Washington, DC, USA, 2017.

2. Ashik, U.P.M.; Wan Daud, W.M.A.; Hayashi, J.-i. A review on methane transformation to hydrogen and nanocarbon: Relevance of catalyst characteristics and experimental parameters on yield. Renew. Sustain. Energy Rev. 2017, 76, 743-767. [CrossRef]

3. Full Mauna Loa $\mathrm{CO}_{2}$ Record; ESRL Global Monitoring Division, Global Greenhouse Gas Reference Network: Boulder, CO, USA, 2018. 
4. Trends in Atmospheric Methane; ESRL Global Monitoring Division, Global Greenhouse Gas Reference Network: Boulder, CO, USA, 2018.

5. Gasser, T.; Kechiar, M.; Ciais, P.; Burke, E.J.; Kleinen, T.; Zhu, D.; Huang, Y.; Ekici, A.; Obersteiner, M. Path-dependent reductions in $\mathrm{CO}_{2}$ emission budgets caused by permafrost carbon release. Nat. Geosci. 2018, 11, 830-835. [CrossRef]

6. Shindell, D.; Faluvegi, G.; Seltzer, K.; Shindell, C. Quantified, localized health benefits of accelerated carbon dioxide emissions reductions. Nat. Clim. Chang. 2018, 8, 291-295. [CrossRef] [PubMed]

7. Zain, M.M.; Mohamed, A.R. An overview on conversion technologies to produce value added products from $\mathrm{CH}_{4}$ and $\mathrm{CO}_{2}$ as major biogas constituents. Renew. Sustain. Energy Rev. 2018, 98, 56-63. [CrossRef]

8. Akiyama, T.; Oikawa, K.; Shimada, T.; Kasai, E.; Yagi, J.-I. Thermodynamic Analysis of Thermochemical Recovery of High Temperature Wastes. ISIJ Int. 2000, 40, 286-291. [CrossRef]

9. Abe, K.; Saito, G.; Nomura, T.; Akiyama, T. Limonitic Laterite Ore as a Catalyst for the Dry Reforming of Methane. Energ. Fuel 2016, 30, 8457-8462. [CrossRef]

10. Bradford, M.C.J.; Vannice, M.A. $\mathrm{CO}_{2}$ Reforming of $\mathrm{CH}_{4}$. Catal. Rev. 1999, 41, 1-42. [CrossRef]

11. Wang, Z.; Cao, X.M.; Zhu, J.; Hu, P. Activity and coke formation of nickel and nickel carbide in dry reforming: A deactivation scheme from density functional theory. J. Cat. 2014, 311, 469-480. [CrossRef]

12. Ruckenstein, E.; Wang, H.Y. Carbon Deposition and Catalytic Deactivation during $\mathrm{CO}_{2}$ Reforming of $\mathrm{CH}_{4}$ over $\mathrm{Co} / \gamma-\mathrm{Al}_{2} \mathrm{O}_{3}$ Catalysts. J. Cat. 2002, 205, 289-293. [CrossRef]

13. Nagaoka, K.; Takanabe, K.; Aika, K.-I. Influence of the reduction temperature on catalytic activity of $\mathrm{Co} / \mathrm{TiO} 2$ (anatase-type) for high pressure dry reforming of methane. Appl. Catal. A-Gen. 2003, 255, 13-21. [CrossRef]

14. Ewbank, J.L.; Kovarik, L.; Kenvin, C.C.; Sievers, C. Effect of preparation methods on the performance of $\mathrm{Co} / \mathrm{Al}_{2} \mathrm{O}_{3}$ catalysts for dry reforming of methane. Green Chem. 2014, 16, 885-896. [CrossRef]

15. Myint, M.; Yan, B.; Wan, J.; Zhao, S.; Chen, J.G. Reforming and oxidative dehydrogenation of ethane with $\mathrm{CO}_{2}$ as a soft oxidant over bimetallic catalysts. J. Cat. 2016, 343, 168-177. [CrossRef]

16. Budiman, A.W.; Song, S.-H.; Chang, T.-S.; Shin, C.-H.; Choi, M.-J. Dry Reforming of Methane Over Cobalt Catalysts: A Literature Review of Catalyst Development. Catal. Surv. Asia 2012, 16, 183-197. [CrossRef]

17. Horiuchi, T.; Sakuma, K.; Fukui, T.; Kubo, Y.; Osaki, T.; Mori, T. Suppression of carbon deposition in the $\mathrm{CO}_{2}$-reforming of $\mathrm{CH}_{4}$ by adding basic metal oxides to a Ni/Al $\mathrm{O}_{3}$ catalyst. Appl. Catal. A-Gen. 1996, 144, 111-120. [CrossRef]

18. Daza, C.E.; Gallego, J.; Mondragón, F.; Moreno, S.; Molina, R. High stability of Ce-promoted Ni/Mg-Al catalysts derived from hydrotalcites in dry reforming of methane. Fuel 2010, 89, 592-603. [CrossRef]

19. Li, H.; He, Y.; Shen, D.; Cheng, S.; Wang, J.; Liu, H.; Xing, C.; Shan, S.; Lu, C.; Yang, R. Design an in-situ reduction of $\mathrm{Ni} / \mathrm{C}-\mathrm{SiO}_{2}$ catalyst and new insights into pretreatment effect for $\mathrm{CH}_{4}-\mathrm{CO}_{2}$ reforming reaction. Int. J. Hydrog. Energy 2017, 42, 10844-10853. [CrossRef]

20. Ashik, U.P.M.; Daud, W.M.A.W. Probing the differential methane decomposition behaviors of $n-\mathrm{Ni} / \mathrm{SiO}$, $n-\mathrm{Fe} / \mathrm{SiO}_{2}$ and $n-\mathrm{Co} / \mathrm{SiO}_{2}$ catalysts prepared by co-precipitation cum modified Stober method. RSC Adv. 2015, 5, 67227-67241. [CrossRef]

21. Zhu, J.; Peng, X.; Yao, L.; Tong, D.; Hu, C. $\mathrm{CO}_{2}$ reforming of methane over $\mathrm{Mg}$-promoted Ni/SiO${ }_{2}$ catalysts: The influence of Mg precursors and impregnation sequences. Catal. Sci. Technol. 2012, 2, 529-537. [CrossRef]

22. Mousavi, S.M.; Meshkani, F.; Rezaei, M. Preparation of nanocrystalline Zr, La and Mg-promoted $10 \%$ $\mathrm{Ni} / \mathrm{Ce}_{0.95} \mathrm{Mn}_{0.05} \mathrm{O}_{2}$ catalysts for syngas production via dry reforming reaction. Int. J. Hydrog. Energy 2018, 43, 6532-6538. [CrossRef]

23. Luengnaruemitchai, A.; Kaengsilalai, A. Activity of different zeolite-supported Ni catalysts for methane reforming with carbon dioxide. Chem. Eng. J. 2008, 144, 96-102. [CrossRef]

24. Li, X.-K.; Ji, W.-J.; Zhao, J.; Wang, S.-J.; Au, C.-T. Ammonia decomposition over Ru and Ni catalysts supported on fumed $\mathrm{SiO}_{2}, \mathrm{MCM}-41$, and SBA-15. J. Cat. 2005, 236, 181-189. [CrossRef]

25. Xu, Y.; Du, X.-h.; Li, J.; Wang, P.; Zhu, J.; Ge, F.-j.; Zhou, J.; Song, M.; Zhu, W.-y. A comparison of $\mathrm{Al}_{2} \mathrm{O}_{3}$ and $\mathrm{SiO}_{2}$ supported Ni-based catalysts in their performance for the dry reforming of methane. J. Fuel Chem. Tech. 2019, 47, 199-208. [CrossRef]

26. Thommes, M.; Kaneko, K.; Neimark Alexander, V.; Olivier James, P.; Rodriguez-Reinoso, F.; Rouquerol, J.; Sing Kenneth, S.W. Physisorption of gases, with special reference to the evaluation of surface area and pore size distribution (IUPAC Technical Report). Pure Appl. Chem. 2015, 87, 1051. [CrossRef] 
27. Li, Z.; Wang, Z.; Jiang, B.; Kawi, S. Sintering resistant Ni nanoparticles exclusively confined within $\mathrm{SiO}_{2}$ nanotubes for $\mathrm{CH}_{4}$ dry reforming. Catal. Sci. Technol. 2018, 8. [CrossRef]

28. Yaripour, F.; Shariatinia, Z.; Sahebdelfar, S.; Irandoukht, A. Effect of boron incorporation on the structure, products selectivities and lifetime of H-ZSM-5 nanocatalyst designed for application in methanol-to-olefins (MTO) reaction. Microporous Mesoporous Mater. 2015, 203, 41-53. [CrossRef]

29. Gong, D.; Li, S.; Guo, S.; Tang, H.; Wang, H.; Liu, Y. Lanthanum and cerium co-modified Ni/SiO 2 catalyst for CO methanation from syngas. Appl. Surf. Sci. 2018, 434, 351-364. [CrossRef]

(C) 2019 by the authors. Licensee MDPI, Basel, Switzerland. This article is an open access article distributed under the terms and conditions of the Creative Commons Attribution (CC BY) license (http://creativecommons.org/licenses/by/4.0/). 